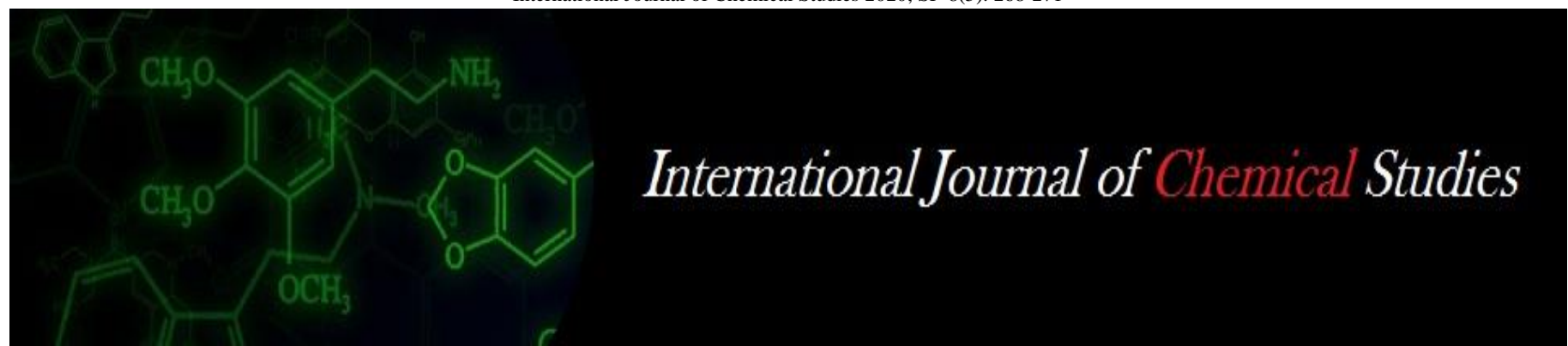

P-ISSN: 2349-8528

E-ISSN: 2321-4902

www.chemijournal.com

IJCS 2020; SP-8(5): 268-271

(C) 2020 IJCS

Received: 16-07-2020

Accepted: 19-08-2020

Swathy AH

College of Agriculture, Vellayan,

Kerala, India

Usha C Thoma

College of Agriculture, Vellayan,

Kerala, India

\section{Weed indices and economics of bajra Napier hybrid as influenced by weed management practices}

\author{
Swathy AH and Usha C Thomas
}

DOI: https://doi.org/10.22271/chemi.2020.v8.i5e.10631

\begin{abstract}
An experiment was conducted to standardise an economic weed management strategy for Bajra Napier Hybrid in the variety of BN hybrid Suguna.The experiment was laid out in randomized block design (RBD) with 9 weed management treatments in three replications. Among the weed management practices, application of oxadiargyl $90 \mathrm{~g} \mathrm{ha}^{-1}$ on 3-5 DAP $f b$ hand weeding on 25 - $30 \mathrm{DAP}\left(\mathrm{T}_{5}\right)$ recorded the lowest weed count, relative density, dry weight and the highest weed control efficiency at 25 and 50 DAP. The highest green fodder yield $\left(154.84 \mathrm{t} \mathrm{ha}^{-1}\right)$, dry fodder yield $\left(30.96 \mathrm{t} \mathrm{ha}^{-1}\right)$ and the lowest weed index was recorded in $\mathrm{T}_{5}$. The highest net returns of ₹ $123758.5 \mathrm{ha}^{-1}$ and significantly higher B:C ratio (1.66) was obtained in $\mathrm{T}_{5}$ suggesting that the treatment $\mathrm{T}_{5}$ (oxadiargyl@ $90 \mathrm{~g} \mathrm{ha}^{-1}$ on 3-5 DAP $f b$ hand weeding on 25-30 DAP) could be adjudged as the economic weed management practice in Bajra Napier hybrid.
\end{abstract}

Keywords: BN hybrid, B:C ratio, net returns, weed control efficiency, weed index

\section{Introduction}

Bajra Napier hybrid is a perennial, erect growing, nutritious, high yielding grass and suitable for cultivation under varying agro-climatic and soil conditions. The grass has gained considerable importance among livestock rearers because of its quick growth, better tillering and rejuvenating capacity. Hybrid Napier once planted supplies fodder continuously and regularly for a period of two to three years.

BN hybrid yield is essentially determined by weed competition that depends on the weed type, weed count, weed density, crop growth stage and weed infestation duration within the field. Weeds not only interfere with crop growth but also cause significant yield and quality losses. Gill (2016) [6]. Responding to the resources available, crop weed competition is the competition between crops and weeds. The identification of critical duration of weed competition is very necessary for efficacious weed management and to avoid damaging effects of weeds on yield and quality of crop. Weeding is a labour -intensive cultivation method. Setting a price on the research and development costs for herbicide use in crop production is extremely difficult. Many farmers soon adopted herbicide use and it became an important part of crop husbandry with some farmers still challenging the widespread use of chemicals in agriculture. Integration of chemical weed management with hand weeding as well as mechanical weeding has been reported as effective and economically viable method of weed management (Ram et al., 2005) ${ }^{[11]}$. The potential role of chemical component in integrated management is well known in many crops whereas the information on selectivity of herbicides in BN hybrid is scanty. Keeping this in view, the present study is undertaken with the objective to standardise an economic weed management strategy for BN hybrid.

\section{Materials and Methods}

The experiment was conducted during 2018-2020 at Instructional farm, College of Agriculture, Vellayani. The treatments were $\mathrm{T}_{1}$ : oxadiargyl $60 \mathrm{~g} \mathrm{ha}^{-1}$ on3-5 DAPfb carfentrazone ethyl $20 \mathrm{~g} \mathrm{ha}^{-1}$ on 25-30 DAP, T2: oxadiargyl $90 \mathrm{~g}_{2}$ ha $^{-1}$ on 3-5 DAP $f b$ carfentrazoneethyl $20 \mathrm{~g}^{-1}$ ha $25-30$ DAP, T T $_{3}$ oxadiargyl $120 \mathrm{~g} \mathrm{ha}^{-1}$ on 3-5 DAP $f b$ carfentrazone ethyl $20 \mathrm{~g} \mathrm{ha}^{-1}$ on 25-30 DAP, T 4 : oxadiargyl $60 \mathrm{~g} \mathrm{ha}^{-1}$ on 3-5 DAP $f b$ hand 
Weeding on 25 - 30 DAP, T : oxadiargyl $90 \mathrm{~g} \mathrm{ha}^{-1}$ on 3-5 DAP $f b$ hand weeding on 25 - 30 DAP, $\mathrm{T}_{6}$ : oxadiargyl $120 \mathrm{~g}$ $\mathrm{ha}^{-1}$ on 3-5 DAP $f b$ hand weeding on 25 - 30 DAP, T: biomulching, $\mathrm{T}_{8}$ : farmers practice (hand weeding at 20 and 40 DAP) and $T_{9}$ : weedy check.

The field was made weed free initially and dry ploughed thrice manually. After leveling the field, 27 plots of size $3 \mathrm{~m} \mathrm{x}$ $3 \mathrm{~m}$ were marked and beds were made. As a source of organic manure dried cow dung having $\mathrm{N}$ content of 0.45 per cent, $\mathrm{P}_{2} \mathrm{O}_{5}$ content of 0.17 per cent and $\mathrm{K}_{2} 0$ content of 0.5 per cent was applied. For the experiment, source of NPK used were urea (46 per cent $\mathrm{N}$ ), factamphos (20 per centN and 20 per cent $\left.\mathrm{P}_{2} \mathrm{O}_{5}\right)$ andmuriate of potash $\left(60\right.$ per cent $\left.\mathrm{K}_{2} \mathrm{O}\right)$. Three nodded cuttings were stuck into the soil at an angle to a depth with the basal end down so that the two nodes stayed within and one above the surface of the soil. A spacing of $60 \mathrm{~cm} \times 60$ $\mathrm{cm}$ was followed. The herbicides tested in the trial were oxadiargyl (80 WP) and carfentrazone ethyl (40\% DF). Spraying of oxadiargyl @ 60, 90 and $120 \mathrm{~g} \mathrm{ha}^{-1}$ on 3-5 DAP and carfentrazone ethyl $20 \mathrm{~g} \mathrm{ha}^{-1}$ on 25-30 DAP was done using hand sprayer of spray volume $500 \mathrm{~L} \mathrm{ha}^{-1}$.

Weed characters were studied at 25 and 50 DAP.Weed species predominant in the experimental field were found, classified and grouped as grassy weeds, broadleaved weeds (BLW) and sedges. Weed count at 25 and 50 DAP in each plot was recordedby using a quadrat $(1 \mathrm{~m} \mathrm{x} 1 \mathrm{~m})$ in two random places. Grasses, sedge and BLW were recorded in each plot and expressed in number $\mathrm{m}^{-2}$. Relative density of group wise weeds were worked and expressed as percentage (Phillips, 1959) ${ }^{[9]}$.

Relative density $(\%)=\frac{\text { Absolute density of a given species }}{\text { Total absolute density of all species }} \times 100$

During each sampling point, weeds removed from each plot were air dried for one day and then dried to obtain a constant weight during $60^{\circ} \pm 5^{\circ} \mathrm{C}$ and expressed as $\mathrm{g} \mathrm{m}^{-2}$.Weed Control Efficiency (WCE) was calculated with the method suggested by Mani and Gautham (1973) ${ }^{[7]}$

$$
\mathrm{WCE}(\%)=\left(\frac{\mathrm{WDC}-\mathrm{WDT}}{\mathrm{WDC}}\right) \times 100
$$

\section{Where}

WDC $=$ Weed dry weight in the unweeded plot $\left(\mathrm{g} \mathrm{m}^{-2}\right)$

WDT $=$ Weed dry weight in the treated plot $\left(\mathrm{g} \mathrm{m}^{-2}\right)$

The WI was calculated by the following formula (Gill and Vijay Kumar, 1969) ${ }^{[5]}$.

$$
\mathrm{WI}(\%)=\left(\frac{\mathrm{X}-\mathrm{Y}}{\mathrm{X}}\right) \times 100
$$

\section{Where}

$\mathrm{X}=$ Yield $\left(\mathrm{kg} \mathrm{ha}^{-1}\right)$ from minimum weed competition plot (maximum yield)

$\mathrm{Y}=$ Yield $\left(\mathrm{kg} \mathrm{ha}^{-1}\right)$ of treatment plot for which the weed index is to be worked out

The Bajra Napier hybrid grass was cut near the ground level in each plot and the fresh weight was recorded and green fodder yield was expressed as $\mathrm{t} \mathrm{ha}^{-1}$. A weighted representative sample of green forage was obtained from each plot and was dried to constant weight in an oven at $70^{\circ} \mathrm{C}$. Total DMY was calculated from the dry weight of the sample and expressed as $\mathrm{t}$ ha ${ }^{-1}$. The crude protein content was calculated by multiplying the plant's nitrogen content by 6.25 (Simpson et al., 1965) ${ }^{[13]}$. The crude fibre content was determined by AOAC method (AOAC, 1975) ${ }^{[1]}$.

Economics of cultivation was worked out based on the cost of cultivation and market price of the fodder crop.

The net returns and benefit: cost ratio were calculated as follows:

Net returns $\left(₹ \mathrm{ha}^{-1}\right)=$ Gross income - Total expenditure

$$
\text { Benefit: Cost ratio }=\frac{\text { Gross income }}{\text { Total expenditure }}
$$

\section{Results and Discussions}

\section{Weed Flora and Weed count}

The predominant grassy weeds present in the experimental field were Digitaria sanguinalis, Eleusine indica, Digitaria ciliaris, Dactyloctenium aegyptium, broad leaf weeds were Chenopodium album, Eclipta prostrata, Amaranthus viridis and Phyllanthus niruri and the only one sedge present in the field was Cyperus rotundus. At 25 DAP sedges were predominant followed by broad leaved weeds and grass weeds. At 50 DAP, broad leaved weeds were predominant followed by grasses and sedges. Gill (2016) ${ }^{[6]}$ observed the presence of grasseslike Acrachne racemosa, Dactyloctenium aegyptium, Eleusine indica, broad leaved weeds like Amaranthus viridis, Chenopodium album and the sedge Cyeprus rotundus in BN hybrid. With respect to total weed count, at 25 and 50 DAPthe lowest total weed count, 1.68 and1.27 respectively was observed in $\mathrm{T}_{5}$ (oxadiargyl $90 \mathrm{~g} \mathrm{ha}^{-1}$ on 3-5 DAP $f b$ hand weeding on 25 - 30 DAPand $\mathrm{T}_{9}$ (weedy check) recorded thehighesttotal weed count, 45.49 and 16.66respectively). The reduction of weed count in $\mathrm{T}_{5}$ (oxadiargyl $90 \mathrm{~g} \mathrm{ha}^{-1}$ on 3-5 DAPfb hand weeding on 25 - 30 DAP) might be due to the effective control of weeds by the preemergence application of oxadiargyl along with the removal of weeds by hand weeding. Similar findings have been reported by Satao and Padole (1994) ${ }^{[12]}$ and Charles (2013) ${ }^{[3]}$, Prabhu and Palsaniya (2016) ${ }^{[10]}$ and Choudhary et al. $(2017)^{[4]}$.

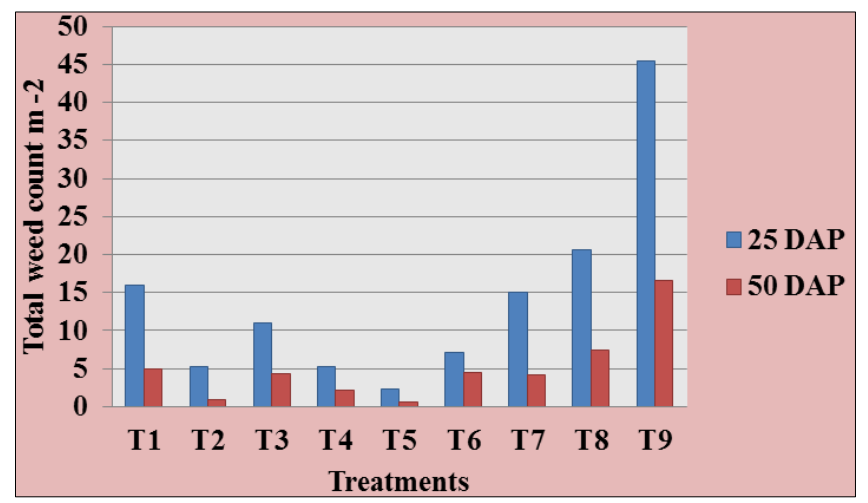

Fig 1: Weed count as influenced by weed management practice

\section{Weed relative density and weed dry weight}

The relative density and dry weight of grassy weeds, broad leaved weeds and sedges was higher at 25 DAP and reduced thereafter). At 25 DAP, analogous to weed count, lower weed dry matter $\left(0.54 \mathrm{~g} / \mathrm{m}^{2}\right)$ was observed in $\mathrm{T}_{5}$ (oxadiargyl $90 \mathrm{~g} \mathrm{ha}^{-}$ 1 on 3-5 DAP $f b$ hand weeding on 25 - 30 DAP) and the treatment $\mathrm{T}_{9}$ (weedy check) recorded significantly higher weed dry matter $\left(16.81 \mathrm{~g} / \mathrm{m}^{2}\right)$ (Table 1$)$.Similarly at 50 DAP, the lowest weed dry matter $\left(0.25 \mathrm{~g} / \mathrm{m}^{2}\right)$ was observed in $T_{5}$ 
(oxadiargyl $90 \mathrm{~g} \mathrm{ha}^{-1}$ on 3-5 DAP $f b$ hand weeding on 25 - 30 DAP) and significantly higher weed dry matter $\left(12.11 \mathrm{~g} / \mathrm{m}^{2}\right)$ was observed in $\mathrm{T}_{9}$ (weedy check). The weed dry weight in almost all treatments corresponded to the weed count that was recorded therein. Similar findings were reported by Singh et al. (2011) ${ }^{[14]}$ and Prabhu and Palsaniya (2016) ${ }^{[10]}$.

\section{Weed Control Efficiency}

At 25 and 50 DAP, the highest weed control efficiency (Table 1) was recorded in $T_{5}$ (oxadiargyl $90 \mathrm{~g} \mathrm{ha}^{-1}$ on 3-5 DAPfb hand weeding on 25 - 30 DAP) which was on par withT 2 (oxadiargyl $90 \mathrm{~g} \mathrm{ha}^{-1}$ on 3-5 DAP fbcarfentrazoneethyl $20 \mathrm{~g}$ $\mathrm{ha}^{-1}$ on 25-30 DAP) and $\mathrm{T}_{4}$ (oxadiargyl $60 \mathrm{~g} \mathrm{ha}^{-1}$ on 3-5 DAPfb hand weeding on 25 - $30 \mathrm{DAP})$. The higher weed control efficiency achieved in these treatments may be attributed to the substantial reduction of weed dry matter due to successful weed control by herbicide applicationor through the integration of chemical and cultural methods. Patel et al. (2000) ${ }^{[8]}$ also reported that the integrated methods showed superiority over single methods. Similar results were recorded by Tiwari et al. (2011) ${ }^{[16]}$ and Charles (2013) ${ }^{[3]}$.

Table 1: Effect of weed management practices on total weed dry matter and weed control efficiency

\begin{tabular}{|c|c|c|c|c|}
\hline & \multicolumn{2}{|c|}{ Weed dry matter, $\mathbf{g} / \mathbf{m}^{2}$} & \multicolumn{2}{|c|}{ Weed control efficiency, \% } \\
\hline Treatments & 25 DAP & 50 DAP & 25 DAP & 50 DAP \\
\hline $\mathrm{T}_{1}$ & 8.43 & 2.82 & $49.52(7.44)$ & $96.65(8.70)$ \\
\hline $\mathrm{T}_{2}$ & 1.22 & 0.35 & $92.46(8.99)$ & $96.82(9.54)$ \\
\hline $\mathrm{T}_{3}$ & 6.13 & 1.04 & $63.27(7.74)$ & $76.55(7.94)$ \\
\hline $\mathrm{T}_{4}$ & 1.67 & 0.39 & $89.96(9.48)$ & $96.38(9.47)$ \\
\hline $\mathrm{T}_{5}$ & 0.54 & 0.26 & $96.72(9.61)$ & $98.19(9.90)$ \\
\hline $\mathrm{T}_{6}$ & 3.25 & 0.42 & $80.98(7.94)$ & $90.18(8.59)$ \\
\hline $\mathrm{T}_{7}$ & 7.49 & 2.82 & $55.77(7.06)$ & $75.96(7.27)$ \\
\hline $\mathrm{T}_{8}$ & 12.45 & 3.17 & $25.10(4.69)$ & $74.03(7.89)$ \\
\hline $\mathrm{T}_{9}$ & 16.81 & 12.11 & $0(0)$ & $0(0)$ \\
\hline $\mathrm{SEm}( \pm)$ & 0.24 & 0.12 & 0.46 & 0.16 \\
\hline $\mathrm{CD}(0.05)$ & 0.46 & 0.24 & 1.40 & 0.48 \\
\hline
\end{tabular}

Figures in parenthesis denote transformed values

\section{Weed Index}

The treatment $\mathrm{T}_{5}$ (oxadiargyl $90 \mathrm{~g} \mathrm{ha}^{-1}$ on 3-5 DAP $f b$ hand weeding on 25 - 30 DAP) which recorded the lowest total weed dry weight and the highest yield was taken as the best treatment for calculating weed index. During first, second and third harvest the treatment $\mathrm{T}_{5}$ recorded zero weed index and it was significantly superior over other treatments. Weedy check recorded a weed index of 49.39, 46.87 and 45.01 per cent respectively, during first, second and third harvest. An increase of 47.14 per cent green fodder yield and 47.15 per cent dry fodder yield was recorded in the treatment $T_{5}$ (oxadiargyl $90 \mathrm{~g} \mathrm{ha}^{-1}$ on 3-5 DAPfb hand weeding on 25 - 30 DAP) over $\mathrm{T}_{9}$ (weedy check).

\section{Yield and quality attributes}

The treatment $\mathrm{T}_{5}$ (oxadiargyl $90 \mathrm{~g} \mathrm{ha}^{-1}$ on 3-5 DAPfb hand weeding on 25 - 30 DAP) recorded significantly higher green fodder yield of 54.09, 50.12 and $50.62 \mathrm{t} \mathrm{ha}^{-1}$, respectively during the first, second and third harvest and the treatment $\mathrm{T}_{5}$ was followed by $\mathrm{T}_{2}$ (oxadiargyl $120 \mathrm{~g} \mathrm{ha}^{-1}$ on 3-5 DAP $f b$ carfentrazone ethyl $20 \mathrm{~g} \mathrm{ha}^{-1}$ on 25-30 DAP- $45.09 \mathrm{t} \mathrm{ha}^{-1}$ ). The treatment $\mathrm{T}_{9}$ (weedy check) recorded the lowest green fodder yield of 27.34, 26.64 and $27.85 \mathrm{t} \mathrm{ha}^{-1}$, respectively at all the three harvests. Results on dry fodder yield followed the same trend of green fodder yield. The treatment $\mathrm{T}_{5}$ (oxadiargyl $90 \mathrm{~g}$ ha-1 on 3-5 DAP $f b$ hand weeding on 25 - 30 DAP) recorded significantly higher dry fodder yield of 10.81, 10.02 and $10.12 \mathrm{t} \mathrm{ha}^{-1}$, respectively during first, second and third harvests and was significantly superior to other treatments. Weedy check $\left(\mathrm{T}_{9}\right)$ recorded the lowest dry fodder yields of 5.46, 5.82 and $5.57 \mathrm{t} \mathrm{ha}^{-1}$, respectively during first, second and third harvests.

Table 2: Effect of weed management practices on total green and dry fodder yield, $\mathrm{t} \mathrm{ha}^{-1}$

\begin{tabular}{|c|c|c|}
\hline Treatments & Total green Fodder yield & Total dry Fodder Yield \\
\hline $\mathrm{T}_{1}$ & 114.63 & 22.92 \\
\hline $\mathrm{T}_{2}$ & 138.68 & 27.73 \\
\hline $\mathrm{T}_{3}$ & 124.29 & 24.85 \\
\hline $\mathrm{T}_{4}$ & 125.18 & 25.03 \\
\hline $\mathrm{T}_{5}$ & 154.84 & 30.96 \\
\hline $\mathrm{T}_{6}$ & 120.84 & 24.16 \\
\hline $\mathrm{T}_{7}$ & 114.58 & 22.91 \\
\hline $\mathrm{T}_{8}$ & 97.27 & 19.45 \\
\hline $\mathrm{T}_{9}$ & 81.84 & 16.36 \\
\hline $\mathrm{SE}$ & 2.58 & 0.51 \\
\hline $\mathrm{CD}$ & 7.81 & 1.56 \\
\hline
\end{tabular}

The highest crude protein content $(9.70 \%)$ was recorded in $\mathrm{T}_{2}$ (Oxadiargyl $90 \mathrm{~g} \mathrm{ha}^{-1}$ on 3-5 DAP fbCarfentrazoneethyl $20 \mathrm{~g}$

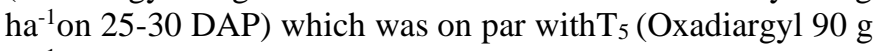
$\mathrm{ha}^{-1}$ on 3-5 DAPfb Hand weeding on 25 - 30 DAP -9.40\%) and the lowest crude protein was recorded in $\mathrm{T}_{9}$ (weedy check - 8.14\%). The lowest crude fibre content was recorded in $\mathrm{T}_{2}$ (Oxadiargyl $90 \mathrm{~g} \mathrm{ha}^{-1}$ on 3-5 DAP $f b$ Carfentrazoneethyl $20 \mathrm{~g}$ ha $^{-1}$ on 25-30 DAP-35.2\%) which was on par with $\mathrm{T}_{5}$ (Oxadiargyl $90 \mathrm{~g} \mathrm{ha}^{-1}$ on 3-5 DAPfb Hand weeding on 25 - 30 DAP- $36.03 \%)$. The highest crude fibre content (38.11\%) was recorded in $\mathrm{T}_{9}$ (weedy check).

\section{Economics of cultivation}

The total cost of cultivation was higher in $\mathrm{T}_{3}$ (oxadiargyl 120 $\mathrm{g} \mathrm{ha}^{-1}$ on 3-5 DAP $f b$ carfentrazone ethyl $20 \mathrm{~g} \mathrm{ha}^{-1}$ on 25-30 DAP) mainly because of the higher dose and cost of the herbicides used. The lowest cost of cultivation was observed in $\mathrm{T}_{7}$ (bio mulching), $\mathrm{T}_{8}$ (farmers practice - hand weeding at 20 and $40 \mathrm{DAP}$ ) and $\mathrm{T}_{9}$ (weedy check) since in there was no additional cost due to treatments.

Among weed control treatments, $\mathrm{T}_{5}$ (oxadiargyl $90 \mathrm{~g} \mathrm{ha}^{-1}$ on 3-5 DAP $f b$ hand weeding on 25 - 30 DAP) recorded highest gross returns and the lowest was reported in $\mathrm{T}_{9}$ (weedy check). This might be due to the effect of treatment which decreased weed crop competition resulting into highest fodder yield. Choudary et al. (2017) ${ }^{[4]}$ also reported similar findings. Also highest net returns was obtained in $\mathrm{T}_{5}$ (Oxadiargyl $90 \mathrm{~g}$ $\mathrm{ha}^{-1}$ on 3-5 DAPfb Hand weeding on 25 - 30 DAP) and lowest in $\mathrm{T}_{9}$ (weedy check). Net returns are the basis for adoption of any new technology.

Weed management practices had significant effect on the B:C ratio. Significantly higher $B: C$ ratio (1.66) was obtained in $T_{5}$ (oxadiargyl $90 \mathrm{~g} \mathrm{ha}^{-1}$ on 3-5 DAPfb hand weeding on 25 - 30 DAP) due to the highest fodder yield which ultimately resulted in the highest net returns. Similar findings were reported by Sharma and Singh(2010). Significantly lower B:C ratio $(0.88)$ was obtained in weedy check in which the net returns was lower due to the reduction in green fodder yield due to heavy weed infestation. Similar results were reported by Walia et al. (2007) ${ }^{[17]}$, Sunitha et al. (2010) ${ }^{[15]}$ and Arvadiya et al. (2012) ${ }^{[2]}$. 
Table 3: Economics of cultivation of hybrid napier

\begin{tabular}{|c|c|c|c|c|c|c|}
\hline Treatments & $\begin{array}{c}\text { Cost of cultivation excluding treatments } \\
\left(\mathrm{Rs}^{\left.\mathrm{h} \mathrm{ha}^{-1}\right)}\right.\end{array}$ & \begin{tabular}{|c|} 
Additional cost due to treatments \\
$\left(\right.$ Rs. ha $\left.^{-1}\right)$
\end{tabular} & $\begin{array}{c}\text { Total cost of cultivation } \\
\left(\text { Rs. } \text { ha }^{-1}\right)\end{array}$ & \begin{tabular}{|c|}
$\begin{array}{c}\text { Gross returns } \\
\left(\text { Rs. } \text { ha }^{-1}\right)\end{array}$ \\
\end{tabular} & $\begin{array}{c}\text { Net returns } \\
\left(\text { Rs. ha }{ }^{-1}\right)\end{array}$ & $\begin{array}{l}\text { Benefit: Cost } \\
\text { ratio }\end{array}$ \\
\hline $\mathrm{T}_{1}$ & \begin{tabular}{|c|}
184769 \\
\end{tabular} & \begin{tabular}{|c|}
1013 \\
\end{tabular} & 185782 & 229275.00 & 43493.00 & 1.23 \\
\hline $\mathrm{T}_{2}$ & 184769 & 1400 & 186169 & 277375.00 & 91206.00 & 1.48 \\
\hline $\mathrm{T}_{3}$ & 184769 & 1786 & 186555 & 248593.80 & 62038.77 & 1.33 \\
\hline $\mathrm{T}_{4}$ & 184769 & 773 & 185542 & 250375.00 & 64833.00 & 1.34 \\
\hline $\mathrm{T}_{5}$ & 184769 & 1160 & 185929 & 309687.50 & 123758.50 & 1.66 \\
\hline $\mathrm{T}_{6}$ & 184769 & 1546 & 186315 & 241683.40 & 55368.40 & 1.29 \\
\hline $\mathrm{T}_{7}$ & 184769 & 0 & 184769 & 229178.80 & 44409.80 & 1.24 \\
\hline $\mathrm{T}_{8}$ & 184769 & 0 & 184769 & 194541.70 & 9772.66 & 1.05 \\
\hline $\mathrm{T}_{9}$ & 184769 & 0 & 184769 & 163683.80 & -21085.2 & 0.88 \\
\hline
\end{tabular}

Price of $1 \mathrm{~kg}$ green fodder = Rs. 2.00, Price of 22.5g Oxadiargyl =Rs.290, Price of 25g Carfentrazone ethyl=Rs.300

\section{Conclusion}

Considering the weed control efficiency, weed index, net returns and B: C ratio, treatment oxadiargyl@ $90 \mathrm{~g} \mathrm{ha}^{-1}$ on 3-5 DAP $f b$ hand weeding on 25-30 DAP could be adjudged as the economic weed management practice in Bajra Napier hybrid.

\section{References}

1. AOAC. [Association of Official Analytical Chemists]. Official and Tentative Methods of Analysis. Association of Official Analytical Chemists, Washington, D.C. 1975, 130-137.

2. Arvadiya LK, Raj VC, Patel TU, Arvadla MK. Influence of plant population and weed management on weed flora and productivity of sweet com (Zea mays). Indian $\mathbf{J}$ Agron. 2012; 57(2):162-167.

3. Charles MB. Effect of integrated weed management on green forage yield and quality of oat (Avena sativa L.). M. Sc. thesis, Mahatma Phule Krishi Vidyapeeth, Rahuri, 2013, 102.

4. Choudhary S, Chopra NK, Chopra NK, Singh M, Kumar $\mathrm{R}$, Kushwaha M. Influence of nitrogen levels and weed management practices on yield and quality of forage pearl millet (Pennisetum glaucum L.). Indian J Anim. Nutr. 2017; 34(1):64-69.

5. Gill GS and Vijayakumar R. Weed index-A new method of reporting weedicidal trials. In Proc. $2^{\text {nd }}$ Weed Control Seminar, 1969, 14-17.

6. Gill PK. Weed management and water productivity of BN hybrid in relation to mulch and irrigation regimes. $\mathrm{Ph}$ D thesis, Punjab Agricultural University, Ludhiana, 2016, 189.

7. Mani VS, Guatam KC. Chemical weed control, effective and economical. Indian farming. 1973; 22:191-12.

8. Patel GN, Patel GJ, Goyal SN, Patel BG. Integrated weed management in rabi maize. Gujarat Agric. Univ. Res. J. 2000; 25(2):88-90.

9. Phillips EA. Methods of vegetation study- ecology workbook. Henry Holt and company, 1959, 144.

10. Prabhu G, Palsaniya DR. Screening of herbicides for effective weed control in Bajra Napier hybrid. Range Mgmt. Agrofor. 2016; 37(1):73-78.

11. Ram B, Chaudhary GR, Jat AS. Effect of weed management practices on yield, nutrient uptake and quality of pearl millet (Pennisetum glaucum) grown under different intercropping systems. Indian J Agric. Sci. 2005; 75:749-752.

12. Sataom RN, Padole SG. Effect of weed control on growth and yield of late-sown wheat (Triticum aestivum). Indian J Agron. 1994: 39(4):645-647.

13. Simpson JE, Adair CR, Kohler GD, Dawson EN, Debald HA, Kester EB et al. Quality Evaluation of Foreign and
Domestic Rices. Technical Bulletin No. 1331 series, USDA, 1965, 250.

14. Singh VK, Dixit V, Singh R, Barthwal A. Efficacy of mechanical, cultural and chemical methods on weed suppression and yield of lentil. Indian J Weed Sci. 2011; 43(4):192-194.

15. Sunitha N, Reddy MP, Sadhineni M. Effect of cultural manipulation and weed management practices on weed dynamics and performance of sweet corn (Zea mays L.). Indian J Weed Sci. 2010; 42:184-188.

16. Tiwari RK, Dwivedi BS, Deshmukh G, Pandey K, Jha, A. Effect of weed control treatments on growth of little seed cannary grass and productivity of wheat. Indian $\mathbf{J}$ Weed Sci. 2011; 43:239-240.

17. Walia US, Singh S, Singh B. Integrated control of hardy weeds in maize (Zea mays L.). Indian J Weed Sci. 2007; 39:17-20. 